\title{
ANALISIS KOMPETENSI GURU FISIKA \\ DALAM MENGIMPLEMENTASIKAN KTSP \\ DI SMKN DI PROVINSI LAMPUNG
}

\author{
Sunaryo \\ FMIPA Universitas Negeri Jakarta (e-mail: naryounj@yahoo.co.id; \\ Telp: 021-4894909)
}

\begin{abstract}
An Analysis of Physics Teachers' Competencies in Implementing the School-Based Curriculum in State Vocational High Schools in Lampung Province. This study aims to investigate vocational high school physics teachers' competencies in implementing the School-Based Curriculum. The sample consisted of 37 physics teacher from 27 state vocational high schools. Based on the data analysis, it can be concluded that physics teachers' competencies in physics learning are good and they can satisfy the standards in accordance with their educational backgrounds. However, they need support in the form of laboratory facilities to improve learning outcomes. They are expected to understand the fundamental knowledge including logical, analytic, and systemic thinking, and meet the competence standards in the educational system. They also need information technology facilities to enhance their teaching skills.
\end{abstract}

Keywords: teachers' competencies, the School-Based Curriculum

\section{PENDAHULUAN}

Fisika adalah salah satu ilmu dasar (basic science) yang menjadi pondasi dalam pola berpikir individu untuk dikembangkan menjadi pendukung utama dalam pemecahan masalah, khususnya dengan penerapan ilmu praktis. Sejalan dengan pelaksanaan pendidikan di SMK yang berkaitan dengan ilmu terapan dengan tuntutan kompetensi peserta didik, para guru bidang studi Fisika dituntut harus kompeten dan profesional dalam melayani peserta didik pada proses pembelajaran. Hal ini menjadi penting. Mengingat fisika sebagai ilmu dasar (basic sience) yang akan membentuk pola pikir analitis, logis, dan sistemik pada peserta didik. Proses pembelajaran di sekolah yang sering mengalami banyak hambatan, tantangan serta tuntutan lebih khusus pada SMK, diharapkan mampu menghasilkan lulusan yang memiliki kompetensi dasar standar dan terampil serta mandiri. Untuk itu, sistem pembelajaran di SMK memerlukan strategi, metode dan target yang harus dimiliki oleh guru fisika atau kompetensi guru yang mumpuni serta mampu menghasilkan peserta didik yang memiliki kompetensi standar yang diharapkan.

Pelaksanaan pendidikan di SMK di bawah pengawasan Direktorat Pendidikan Menengah Kejuruan, Kementeri- 
an Pendidikan Nasional telah banyak melakukan perubahan dinamis dalam rangka mendukung program pengembangan pendidikan kejuruan untuk menghasilkan manusia-manusia terampil dan produktif.

Program pengembangan pendidikan yang dicanangkan oleh pemerintah dalam rangka meningkatkan produktivitas SDM adalah membuka sekolahsekolah yang menghasilkan manusia terampil dengan memiliki keterampilan untuk melakukan kegiatan produktif setelah mengenyam pendidikan. Hal ini terbukti dari upaya pemerintah membuka dan atau mengembangkan SMK yang diharapkan menghasilkan alumni yang siap kerja. Upaya tersebut akan terealisasikan dengan baik dalam aktivitas yang komprehensif.

Perubahan pengelolaan sistem pendidikan dari sentralistik ke desentralistik sudah dimulai sejak diberlakukannya Undang-Undang No. 32 Tahun 2004 tentang Pemerintah Daerah telah memengaruhi penyelenggaraan sistem pemerintahan di Indonesia, sekaligus pelaksanaan sistem pendidikan menyatu dalam prosesnya. Perubahan pengelolaan sistem tersebut didasarkan pertimbangan adanya dampak kurang baik dalam peneyelenggaraan pendidikan di Indonesia menurut hasil studi yang dilakukan Depdiknas (BNS, 2006:5).

Hamalik (2002:1-2)memberikan penjelasan mengenai faktor-faktor yang menyebabkan rendahnya mutu pendidikan di Indonesia, yaitu: (1) kebijakan penyelenggaraan pendidikan nasional menggunakan pendekatan fungsi produksi pendidikan atau input-outcome analisis yang tidak dilaksanakan secara konsekuen; (2) penyelenggaraan pendidikan nasional dilakukan secara birokratik-sentralistik; dan (3) peran serta masyarakat khususnya orang tua peserta didik dalam peneyelenggaraan pendidikan sangat minim.

Hasil studi di atas memberikan petunjuk bahwa kebijakan sentralistik dan pengabaian peran serta masyarakat memberikan dampak yang kurang baik bagi penyelenggaraan pendidikan di Indonesia.

Pemberlakuan pelaksanaan otonomi daerah yang diikuti dengan otonomi pendidikan diharapkan menjadi jalan terbaik untuk meningkatkan mutu pendidikan di Indonesia, termasuk meningkatkan partisipasi masyarakat dalam pendidikan. Pemberlakuan otonomipendidikan pada pemerintah daerah bukan penyerahan urusan pendidikan pada daerah, melainkan lebih dari itu, yaitu pada satuan pendidikan.

Salah satu wujud nyata pemberian otonomi pendidikan pada satuan pendidikan adalah diberlakukannya manajemen berbasis sekolah (MBS). Wujud lain pemberlakukan otonomi pendidikan pada satuan pendidikan adalah pemberian wewenang kepada satuan pendidikan untukmengembangkan dan menetapkan Kurikulum Tingkat Satuan Pendidikan atau (KTSP). Bagaimana implementasi dari semua kebijakan terkait dengan pelaksanaan pendidikan tersebut?

\section{Kurikulum Tingkat Satuan Pendidik- an}

Kurikulum Tingkat Satuan Pendidikan (KTSP) adalah kurikulum operasional yang disusun oleh dan dilaksana- 
kan di masing-masing satuan pendidikan (PP No. 19 tahun 2005; BSNP, 2006: 5). KTSP dikembangkan oleh kelompok atau satuan pendidikan dan komite sekolah/madrasah di bawah koordinasi dan supervisi Dinas Pendidikan dan Kandepag Kabupaten/Kota untuk Pendidikan Dasar dan Dinas pendidikan/ kanwil depag provinsi untuk Pendidikan Menengah dan Pendidikan Khusus (UU RI No. 20/2003: Kunandar, 2007: 32).

Dalam penyusunan KTSP (BSNP, 2006; Kunandar, 2007:26; Mulyasa, 2008: 75), dijelaskan bahwa komponen KTSP terdiri atas (1) visi, misi dan tujuan satuan pendidikan; (2) struktur dan muatan KTSP: mata pelajaran, muatan lokal pengembangan diri, beban belajar, ketuntasan belajar, kenaikan kelas dan kelulusan, penjurusan, pendidikan kecakapan hidup, pendidikan berbasis keunggulan lokal dan global; (3) kalender pendidikan; dan (4) pengembangan silabus. Berdasarka komponen KTSP tersebut secara garis besar KTSP terbagi dalam dua dokumen pokok, yaitu dokumen satu yang memuat pokok-pokok kurikulum (komponen kesatu hingga ketiga) dan dokumen dua yang memuat silabus untuk masing-masing mata pelajaran, muatan lokal dan program pengembangan diri (komponen keempat). Jadi, setiap satuan pendidikan seyogyanya memiliki dua dokumen untuk dapat dikatakan telah mengembangkan KTSP secara lengkap.

Ada beberapa prinsip yang harus diperhatikan dalam mengembangkan KTSP, yaitu sebagai berikut (BSNP, 2006:56).
- Terpusat pada potensi, perkembangan, kebutuhan dan kepentingan peserta didik dan lingkungannya

Kurikulum dikembangkan berdasarkan prinsip bahwa peserta didik memiliki posisi sentral untuk mengembangkan kompetensinya agar menjadi manusia yang beriman dan bertakwa kepada Tuhan Yang Maha Esa, berakhlak mulia, sehat, berilmu, cakap, kreatif, mandiri, dan menjadi warga negara yang demokratis dan bertanggung jawab. Untuk mendukung pencapaian tujuan tersebut pengembangan kompetensi peserta didik disesuaikan dengan potensi, perkembangan, kebutuhan dan kepentingan peserta didik, serta tuntutan lingkungan. Memiliki posisi sentral berarti kegiatan pembelajaran berpusat pada peserta didik.

\section{- Beragam dan terpadu}

Kurikulum dikembangkan dengan memperhatikan keragaman karakteristik peserta didik, kondisi daerah, jenjang dan jenis pendidikan, serta menghargai dan tidak diskriminatif terhadap perbedaan agama, suku, budaya, adat istiadat, status sosial ekonomi, dan jender. Kurikulum meliputi substansi komponen muatan wajib kurikulum, muatan lokal, dan pengembangan diri secara terpadu, serta disusun dalam keterkaitan dan kesinambungan yang bermakna dan tepat antar substansi.

- Tanggap terhadap perkembangan ilmu pengetahuan, teknologi dan seni

Kurikulum dikembangkan atas dasar kesadaran bahwa ilmu pengetahuan, teknologi dan seni berkembang secara 
dinamis. Oleh karena itu, semangat dan isi kurikulum memberikan pengalaman belajar peserta didik untuk mengikuti dan memanfaatkan perkembangan ilmu pengetahuan, teknologi dan seni.

- Relevan dengan kebutuhan kehidupan

Pengembangan kurikulum dilakukan dengan melibatkan pemangku kepentingan (stakeholder) untuk menjamin relevansi pendidikan dengan kebutuhan kehidupan, termasuk di dalamnya kehidupan kemasyarakatan, dunia usaha dan dunia kerja. Oleh karena itu, pengembangan keterampilan pribadi, berpikir, sosial, akademik, dan vokasional merupakan keniscayaan.

- Menyeluruh dan berkesinambungan

Substansi kurikulum mencakup keseluruhan dimensi kompetensi, bidang kajian keilmuan dan mata pelajaran yang direncanakan dan disajikan secara berkesinambungan antarsemua jenjang pendidikan.

- Belajar sepanjang hayat

Kurikulum diarahkan ke proses pengembangan, pembudayaan, dan pemberdayaan peserta didik agar mampu dan mau belajar yang berlangsung sepanjang hayat. Kurikulum mencerminkanketerkaitan antara unsur-unsur pendidikan formal, nonformal, dan informal dengan memperhatikan kondisi dan tuntutan lingkungan yang selalu berkembang serta arah pengembangan manusia seutuhnya.

- Seimbang antara kepentingan nasional dan kepentingan daerah

Kurikulum dikembangkan dengan memperhatikan kepentingan nasional dan kepentingan daerah untuk membangun kehidupan bermasyarakat, berbangsa dan bernegara.Kepentingan nasional dan kepentingan daerah harus saling memberdayakan dan mengisi sejalan dengan motto Bhineka Tunggal Ika dalam kerangka Negara Kesatuan Republik Indonesia (NKRI).

Dalam pelaksanaannya KTSP diperlukan standarisasi dalam beberapa aspek, di antaranya: (1) standar isi; (2) standar proses; (3) standar kompetensi lulusan; (4) standar pendidik dan tenaga kependidikan; (5) standar sarana dan prasarana; (6) standar pengelolaan; (7) standar pembiayaan; (8) standar penilaian.

Untuk itu, diperlukan agar tatanan sistem di sekolah yang harus cukup mapan mengingat dalam pelaksanaannya, kebersamaan dalam mengelola pendidikan khususnya SMK menjadi bagian yang sangat esenssial. Mengingat luasnya aspek analisis pelaksanaan KTSP di SMK, perlu pembatasan pada aspek kompetensi guru Fisika SMK yang bertanggung jawab pada pelaksanaan pembelajaran di sekolah, khususnya guru Fisika yang akan memberikan landasan berpikir peserta didik, analitis, logis dan sistemik,pada akhirnya akan menghasilkan lulusan yang kompeten, mampu mandiri, dan berkelanjutan.

Kompleksitas masalah pelaksanaan pendidikan dengan rambu-rambu dalam mendukung keberhasilan pendidikan secara komprehensif memerlukan analisis dan riset dengan biaya serta pemikiran yang butuh energi besar. Untuk itu, dilakukan penelitian dengan batasan analisis kompetensi guru fisika dalam mengimplementasikan KTSP bi- 
dang Fisika di SMK di Provinsi Lampung. Keterkaitan pemilihan daerah tersebut dimungkinkan dengan adanya karakter wilayah yang spesifik variasi kondisi daerah ditinjau dari beberapa aspek, geografi, ekonomi, dan dinamika masyarakat dalam memanfaatkan kondisi lingkungannya. Hal itu mengingat bahwa SMK yang ada di Provinsi Lampung yang cukup heterogen.

\section{METODE}

Penelitian ini merupakan penelitian deskriptif dengan pendekatan kuantitatif. Penelitian dilaksanakan dengan mengambil lokasi di Provinsi Lampung dengan sampel SMK Negeri (SMKN). Pemilihan sampel dilakukan dengan random sampling terstruktur dengan pertimbangan kegiatan pembelajaran Fisika yang ada pada SMK Negeri tersebut diharapkan mampu menjadikan fondasi berpikir analitis, logis, sistemik dan dapat dipraktikkan secara langsung dalam ilmu terapan. Dari jumlah SMK Negeri sebanyak 63 sekolah, dipilih random sampling terstruktur sebanyak 24 sekolah terpilih yang mewakili populasi sekolah. SMKN tersampling diharapkan menjadi representasi SMK yang ada. Sampel dipilih SMKN yang memiliki latar belakang ilmu eksakta dan berada di Provinsi Lampung. Penelitian dilakukan dari bulan Juni 2010 s.d. Desember 2010.

Penelitian ini bertujuan untuk membantu pemerintah daerah, khususnya dinas pendidikan setempat dalam membuat pola kebijakan peningkatan SMK dan menyusun rencana pengembangan SMK jangka panjang, khususnya dalam perencanaan kebutuhan guru bidang studi fisika yang sangat diperlukan dalam pembentukan individu yang memiliki sifat kritis, analitis, logis, kreatif, inovatif dalam mencapai target pendidikan nasional, yaitu mampu menghasilkan alumni yang terampil, sigap mampu bekerja mandiri, serta mumpuni.

Sumber data dalam penelitian ini adalah guru fisika yang menjadi responden penelitian. Keseluruhan responden terdiri dari guru bidang studi fisika. Pengumpulan data dilakukan dengan mengisi kuesioner yang berupa isian, pernyataan, pertanyaan dan melakukan survei dilokasi responden. Wawancara dan pengamatan (observasi) dilakukan untuk memperoleh data tentang model dan sistem pembelajaran yang diterapkan dalam kegiatan pembelajaran sehari-hari. Kuesioner disusun dengan rincian yang bermuatan indikator kompentensi guru fisika, dikelompokkan menjadi dua bagian di antaranya kompetensi paedagogik, dan kompetensi profesional, dalam pelaksanaan pembelajaran fisika yang menerapkan KTSP. Analisis dilakukan dengan menggunakan data yang diperoleh melalui survei data primer dan isian kuisioner yang bermuatan indikator kompetensi pedagogik, dan kompetensi profesional.

\section{HASIL DAN PEMBAHASAN}

Deskripsi data yang diperoleh dalam penelitian ini disajikan sebagai dasar analisis kompetensi guru fisika yang didukung oleh beberapa aspek, seperti (1) memahami tuntutan standar profesi yang ada; (2) mencapai kualifikasi dan kompetensi yang dipersyaratkan; (3) membangun hubungan kesejawatan 
yang baik dan luas termasuk lewat organisasi profesi; (4) mengembangkan etos kerja atau budaya kerja yang mengutamakan perlayanan bermutu tinggi kepada konsituen; dan (5) mengadopsi inovasi atau mengembangkan kreativitas dalam pemanfaatan teknologi komunikasi dan informasi mutakhir untuk mengelola dan mengembangkan pembelajaran. Dalam hal ini, tentunya yang sesuai dengan KTSP bidang fisika di SMK.

Dalam kaitan dengan pengembangan dan implementasi KTSP, kompetensi pedagogik dan profesional menjadi lebih dominan karena terkait langsung dengan tugas-tugas pembelajaran. Untuk mengembangkan kurikulum dalam Permendiknas No. 16 Tahun 2007 tentang Standar Kompetensi Pedagogik telah ditentukan bahwa guru harus mampu "mengembangkan kurikulum yang terkait dengan mata pelajaran atau bidang studi pengembangan yang diampu". Untuk standar kompetensi profesional ditentukan bahwa guru harus menguasai standar kompetensi dan kompetensi dasar sesuai mata pelajaran dan bidang studi pengembangan dalam bidang studi fisika.

Guru fisika yang sesuai dengan kondisi globalisasi adalah guru fisika yang mampu menguasai dan mengendalikan perubahan-perubahan yang berwawasan IPTEK (Reif, 1994:17-32). Ciri seorang guru fisika, yaitu memunyai kemampuan dalam mengantisipasi, mengakomodasi, dan mereorientasi terhadap perkembangan yang ada. Selain itu, guru harus selalu berusaha seperti berikut. Pertama, memahami tuntutan standar profesi yang ada. Kedua, men- capai kualifikasi dan kompetensi yang dipersyaratkan. Ketiga, membangun hubungan kesejawatan yang baik dna luas termasuk lewat organisasi profesi. Keempat, mengembangkan etos kerja atau budaya kerja yang mengutamakan perlayanan bermutu tinggi kepada konsituen. Kelima, mengadopsi inovasi atau mengembangkan kreativitas dalam pemanfaatan teknologi komunikasi dan informasi mutakhir untuk mengelola dan mengembangkan pembelajaran.

KTSP adalah kurikulum operasional yang disusun oleh dan dilaksanakan di masing-masing satuan pendidikan. KTSP terdiri dari tujuan pendidikan tingkat satuan pendidikan, struktur dan muatan kurikulum tingkat satuan pendidikan, kalender dan silabus.

KTSP dikembangkan berdasarkan prinsip-prinsip (1) berpusat pada potensi, perkembangan, kebutuhan, dan kepentingan peserta didik dan lingkungannya; (2) beragam dan terpadu, (3) tanggap terhadap perkembangan ilmu pengetahuan, teknologi dan seni, (4) relevan dengan kebutuhan kehidupan; (5) menyeluruh dan berkesinambungan; 6) belajar sepanjang hayat; (7) seimbang antara kepentingan nasional dan kepentingan daerah. Acuan operasional penyusunan KTSP menyangkut problema yang komprehensif dalam tataran kehidupan berbangsa dan bernegara.

Hasil kajian beberapa temuan tentang proses pendidikan menampilkan informasi mendasar peranan guru dan kurikulum adalah pondasi keberhasilan sistem pendidikan sekalipun memerlukan dukungan komponen pendidikan lainnya. Dengan mengedepankan guru 
dan kurikulum sebagai acuan operasional sistem pembelajaran, perlu diangkat analisis singkat ini sebagai bahan kajian lainnya agar dapat memotivasi terjadinya peningkatan kinerja guru sebagai ujung tombak pelaksanaan sistem pembelajaran dalam upaya peningkatan sistem pendidikan di Indonesia pada umumnya.

Hasil survei lewat kegiatan wawancara dengan responden diperoleh beberapa informasi tentang kondisi lingkungan sekolah meliputi yang sarana belajar-mengajar, infrastruktur pendukung dengan rincian (1) sarana belajar- mengajar secara umum sangat baik; (2) laboratorium fisika hanya 2 sekolah yang tersedia dari 27 sekolah SMK yang menjadi sampel; (3) laboratorium teknologi informasi tersedia sekalipun masih memerlukan revitalisasi, mengingat jumlah peserta didik dan guru pengguna yang kurang memadai.

Secara rinci hasil penelitian yang dilakukan didapatkan data kuantitatif dari SMKN di Provinsi Lampung. Dalam tabulasi untuk menentukan informasi guru fisika dalam melaksanakan tugasnya serta mencerminkan kompetensi guru fisika tersaji sebagai berikut.

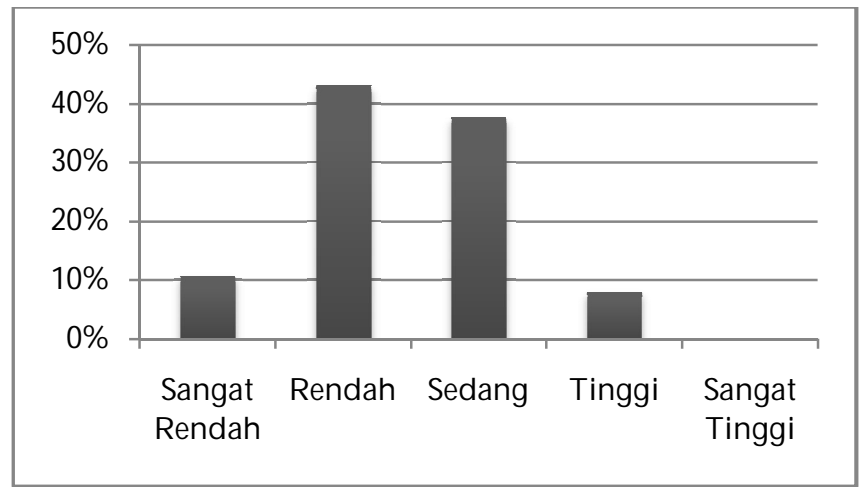

\section{Gambar 1. Histogram Kompetensi Guru Bidang Studi Fisika dalam Penerapan KTSP}

Pada SMK yang menjadi sampel dilakukan observasi langsung dengan pengambilan data primer dari sekolah sekaligus dilakukan wawancara dan pengisian kuesioner untuk mendapatkan informasi kompetensi guru fisika yang berisikan: (1) kualifikasi latar belakang pendidikan guru; (2) pengalaman mengajar; (3) karya ilmiah yang dimiliki; (4) kemampuan membuat rencana proses pembelajaran; (5) kemam- puan membimbing peserta didik; dan (6) hasil karya ilmiah sebagai implementasi hasil pembelajaran. Dengan nilai-nilai kompetensi guru yang dijadikan faktor dalam mengukur tingkat kompetensi guru diketahui hasil dari penelitian ini sebagaimana terurai seperti grafik di atas.

Dari jumlah SMK yang menjadi objek penelitian, banyaknya guru Fisika yang memunyai latar belakang Sarjana 
Pendidikan didapatkan kurang dari $30 \%$ guru.Untuk lama mengajar mata pelajaran fisika, tidak lebih dari 50\% guru yang mempunyai pengalaman mengajar lebih dari sepuluh tahun. Namun, dengan latar belakang guru yang sebagian besar masih berasal dari bidang keteknikan membuat proses pembelajaran dapat dilakukan dengan baik.

Temuan dalam penelitian ini menunjukkan bahwa kebanyakan guru dalam penyampaian materi fisika mengarah langsung pada aplikasi dan belum menekankan peserta didik pada konsep dasar Fisika. Hal ini disebabkan masih kurangnya jumlah guru fisika yang memunyai latar belakang pendidikan fisika sehingga belum memenuhi standar kompetensi profesional .

Sementara itu, masih rendahnya guru fisika yang memunyai karya ilmiah berkaitan dengan mata pelajaran yang diampu merupakan indikasi kurangnya informasi dan akses dalam mendapatkan sumber referensi. Sumber yang terkini diperlukan guru fisika dalam memvariasikan setiap penyampaian materi sehingga peserta didik diharapkan akan lebih memahami materi pembelajaran dan mengetahui perkembangan ilmu pengetahuan. Berdasarkan kuesioner dan hasil wawancara didapatkan hanya $40 \%$ dari guru yang memperoleh fasilitas dalam mengakses sumber informasi terkini di bidang fisika.

Dalam pembuatan rencana proses pembelajaran (RPP), sebanyak $80 \%$ guru fisika SMKN yang menjadi objek penelitian mampu membuatnya dengan baik sesuai standar pedoman pembuatan RPP.

Pada proses pembelajaran interaktif perlu diusahakan adanya hubungan timbal balik antara guru dan peserta didik dan antarpeserta didik. Proses pembelajaran inspiratif yang diselenggarakan dapat mendorong semangat untuk belajar dan timbulnya inspirasi pada peserta didik untuk memunculkan ide baru, mengembangkan inisiatif, dan kreativitas. Proses pembelajaran juga diusahakan agar dapat mengarahkan peserta didik untuk mencari pemecahan masalah, mengembangkan semangat tidak mudah menyerah, dan melakukan percobaan untuk menjawab keingintahuan. Agar proses pembelajaran haruslah dapat memotivasi peserta didik untuk berpartisipasi aktif, guru perlu mendorong peserta didik untuk terlibat dalam setiap peristiwa belajar yang sedang dilakukan. Oleh karena itu, kemampuan guru dalam membimbing peserta didik mempunyai peranan penting dalam proses pembelajaran.

Kemampuan guru fisika di SMKN dalam membimbing peserta didik dapat dikatakan cukup memuaskan. Hal ini dapat dilihat dari keaktifan peserta didik dalam proses belajar mengajar seperti aktif dalam bertanya dan menjawab pertanyaan masalah beraitan tentang konsep dan aplikasi fisika, kerjasama dalam menyelesaikan soal-soal Fisika sesama teman sekelas atau kakak tingkat, dan guru menyisipkan materi pembelajaran fisika yang menjadi isuisu terkini seperti pemanasan global, energi terbarukan, dan pengelolaan lingkungan. 
Guru adalah pendidik profesional. Profesional artinya pekerjaan atau kegiatan yang dilakukan oleh seseorang dan menjadi sumber penghasilan kehidupan yang memerlukan keahlian, kemahiran, atau kecakapan yang memenuhi standar mutu atau norma tertentu serta memerlukan pendidikan profesi (UU RI No. 14 Tahun 2005 tentang Guru dan Dosen). Sebagai pendidik profesional, guru harus memiliki beberapa karakteristik sebagai prinsip profesionalitas, yakni sebagai berikut.

- Memiliki bakat, minat, panggilan jiwa, dan idealism.

- Memiliki komitmen untuk meningkatkan mutu pendidikan, keimanan, ketakwaan, dan akhlak mulia.

- Memiliki kualifikasi akademik dan latar belakang pendidikan sesuai dengan bidang tugas.

- Memiliki kompetensi yang diperlukan sesuai bidang tugas.

- Memiliki tanggung jawab atas pelaksanaan tugas keprofesionalan.

- Memperoleh penghasilan yang ditentukan sesuai dengan prestasi kerja.

- Memiliki kesempatan untuk mengembangkan keprofesionalan secara berkelanjutan dengan belajar sepanjang hayat.

- Memiliki jaminan perlindungan hukum dalam melaksanakan tugas keprofesionalan.

- Memiliki organisasi profesi yang memunyai kewenangan mengatur halhal yang berkaitan dengan tugastugas keprofesionalan guru.

Salah satu ciri profesionalitas guru fisika adalah memiliki kompetensi. KompetensimenurutW. Robert Houston
(Kunandar, 2007:45) adalah suatu "tugas memadai atau pemilikan pengetahuan, keterampilan atau kemampuan yang dituntut untuk jabatan tertentu". Sementara itu, Usman (Kunandar, 2007: 46) mengartikan kompetensi sebagai sesuatu yang menggambarkan kualifikasi atau kemampuan seseorang, baik kualitatif maupun kuantitatif. Ini berarti kompetensi bisa diartikan, pertama, sebagai indikator kemampuan, yaitu perbuatan yang dapat diamati; dan kedua, sebagi konsep yang mencakup aspek kognitif, afektif, dan perbuatan.

Secara legal formal ditentukan bahwa kompetensi adalah seperangkat pengetahuan, keterampilan, dan perilaku yang harus dimiliki, dihayati dan dikuasai oleh guru dalam melaksanakan tugas keprofesionalan (UU No.14/2005). Ada empat kompetensi yang harus dimiliki guru, yaitu kompetensi pedagogik, profesional, kepribadian, dan sosial (UU No. 14 Tahun 2005; PP No. 19 Tahun 2005; Permendiknas No. 16 Tahun 2007). Keempat kompetensi tersebut harus dimiliki guru fisika secara terintegrasi, walaupun aktualisasi bisa berbeda.

Kompetensi guru fisika meliputi hal-hal sebagai berikut.

- Menguasai bahan ajar meliputi:

- menguasai bahan bidang studi fisika dalam kurikulum KTSP;

- menguasai bahan pengayaan/penunjang bidang studi fisika.

- Mengelola program belajar mengajar fisika, meliputi :

- merumuskan tujuan intsruksional.

- mengenal dan dapat menggunakan prosedur instruksional yang tepat; 
- melaksanakan program belajar mengajar;

- mengenal kemampuan anak didik.

- Mengelola kelas, meliputi:

- mengatur tata ruang kelas untuk pelajaran;

- menciptakan iklim belajar mengajar yang serasi.

- Menggunakan media atau sumber, meliputi:

- mengenal, memilih dan menggunakan media;

- membuat alat bantu pelajaran yang sederhana;

- menggunakan laboratorium sebagai proses belajar mengajar.

- menggunakan perpustakaan dalam proses belajar mengajar.

- Menguasai landasan-landasan pendidikan.

- Mengelola interaksi-interaksi belajar mengajar.

- Menilai prestasi peserta didik untuk kepentingan pelajaran.

- Mengenal fungsi layanan dan program bimbingan dan penyuluhan:

- mengenal fungsi dan layanan program bimbingan dan penyuluhan;

- menyelenggarakan layanan bimbingan dan penyuluhan.

- Mengenal dan menyelenggarakan administrasi sekolah.

- Memahami prinsip-prinsip dan menafsirkan hasil penelitianpendidikan guna keperluan pembelajaran.

Dalam mengimplementasikan KTSP guru fisika harus memiliki kompetensi pedagogic, terutama kemampuan menyelenggarakan pembelajaran fisika yang mendidik dan kompetensi profesional terutama menguasai materi, struk- tur, konsep, dan pola pikir keilmuan yang mendukung mata pelajaran fisika yang diampu serta mengembangkan materi pembelajaran fisika secara kreatif. Uraian tersebut di atas mengisyaratkan bahwa sebagai pendidik profesional, seharusnya guru Fisika memiliki kompetensi yang memadai untuk mengembangkan dan mengimplementasikan KTSP Bidang Studi Fisika.

Dalam kenyataanya, diperlukan upaya nyata untuk menguji kebenaran teori tentang potensi guru fisika di SMK yang sangat beragam. Oleh karena itu, diperlukan kajian untuk memetakan kondisi sebenarnya tentang guru fisika yang bertanggung jawab dalam mengimplementasikan pelaksanaan proses pembelajaran yang sesuai dengan tuntutan dan menjawab tantangan dalam pendidikan saat ini.

Dalam jurnal Educational Leadership (Supriyadi, 1998:57) disebutkan bahwa untukmenjadiprofesional, seorang guru dituntut memiliki lima hal. Pertama, guru memunyai komitmen pada peserta didik dan proses belajarnya. Kedua, guru menguasai secara mendalam bahan pelajaran yang diajarkan dan cara mengajarkannya kepada para peserta didik. Ketiga, guru bertanggung jawab memantau hasil belajar peserta didik melalui berbagai teknik evaluasi. Keempat, guru mampu berpikir sistematis tentang apa yang dilakukannya dan belajar dari pengalamannya. Kelima, guru seyogyanya merupakan bagian dari masyarakat dalam lingkungan profesinya.

Atas dasar hal tersebut, guru fisika profesional adalah orang yang memiliki kemampuan dan keahlian khusus da- 
lam bidang keguruan fisika sehingga ia mampu melakukan tugas dan fungsinya sebagai guru fisika dengan kemampuan maksimal. Hal ini sesuai dengan yang dikemukakan Tamyong (Usman, 1995:15) bahwa guru profesional adalah guru yang terdidik dan terlatih dengan baik, serta memiliki pengalaman yang banyak di bidangnya. Pengertian terdidik dan terlatih bukan hanya memperoleh pendidikan formal, melainkan juga harus menguasai berbagai strategi atau teknik di dalam kegiatan belajarmengajar serta menguasai landasanlandasan kependidikan seperti yang tercantum dalam kompetensi guru.

Lebih lanjut Usman (1995:17-18) menyatakan bahwa salah satu kompetensi profesional guru adalah kompetensi atau kemampuan dalam menguasai bahan pembelajaran (materi ajar), baik materi ajar yang digariskan dalam kurikulum maupun materi ajar yang merupakan pengayaan. Selain itu, guru fisika juga diharapkan memiliki kompetensi dalam melaksanakan penelitian sederhana yang nantinya kebiasaan meneliti ini dapat ditularkan kepada teman sesama guru fisika dan kepada peserta didiknya. Guru fisika yang tidak pernah melakukan penelitian, berarti guru yang tidak mau berkembang dan ilmunya tidak akan bertambah. Bila kedua kompetensi tersebut dapat dikembangkan dengan baik oleh guru, hal itu akan mendukung terbentuknya kompetensi profesional guru yang han- dal, guru yang mampu menghadapi perubahan perkembangan teknologi.

Dalam penelitian ini juga dilakukan survei terhadap sarana dan prasarana yang digunakan dalam mendukung kegiatan belajar mengajar. Unsur sarana dan prasarana merupakan media penunjung bagi guru dalam membantu meningkatkan pemahaman dan pengetahuan peserta didik dalam memahami mata pelajaran fisika yang selain memerlukan pemahaman teori juga dibutuhkan pemahaman praktik guna meningkatkan daya nalar peserta didik.

Sarana pendukung pembelajaran secara umum seperti laboratorium fisika tidak dimiliki oleh sekolah, namun kegiatan pembelajaran fisika yang menggunakan dukungan peralatan dilakukan di ruang laboratorium teknik atau laboratorium IT dan lingkungan lainnya. Hasil observasi menunjukkan bahwa guru fisika sadar akan keperluan infrastruktur pendukung proses belajar mengajar sebagai pembuktian fakta dan meningkatkan logika bepikir bagi peserta didik. Hal ini sangat dibutuhkan dalam proses belajar-mengajar karena adanya tujuan pembelajaran dengan tuntutan keluaran peserta didik SMK nantinya bisa memahami secara utuh dan mampu menghasilkan dalam bentuk terapan. Berdasarkan survei yang dilakukan terhadap sarana prasarana serta kelengkapan alat-alat laboratorium dalam mendukung pembelajaran bidang studi fisika, hasilnya dapat dilihat pada histogram berikut. 


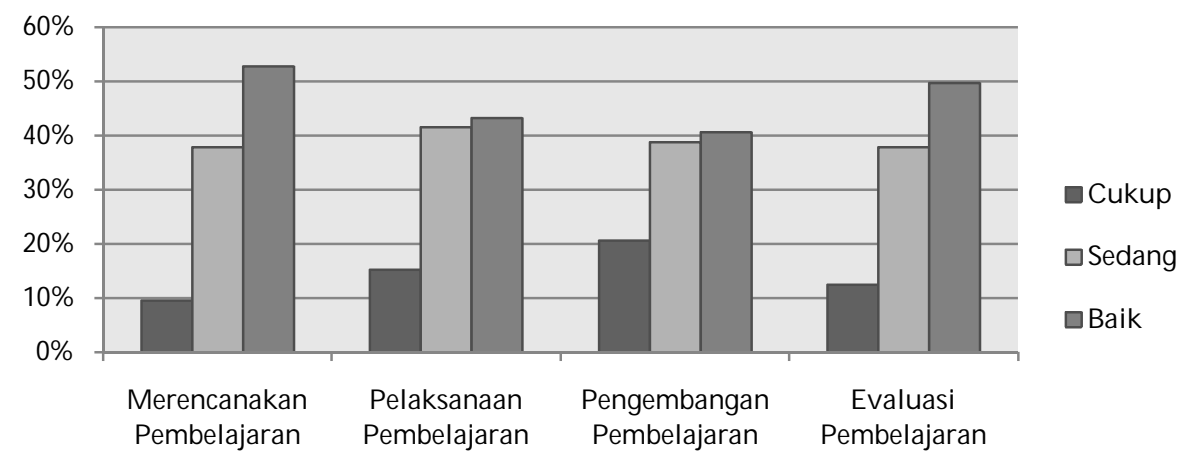

Gambar 2. Histogram Kompetensi Pedagogik Guru Bidang Studi Fisika dalam Pembelajaran di SMKN Provinsi Lampung

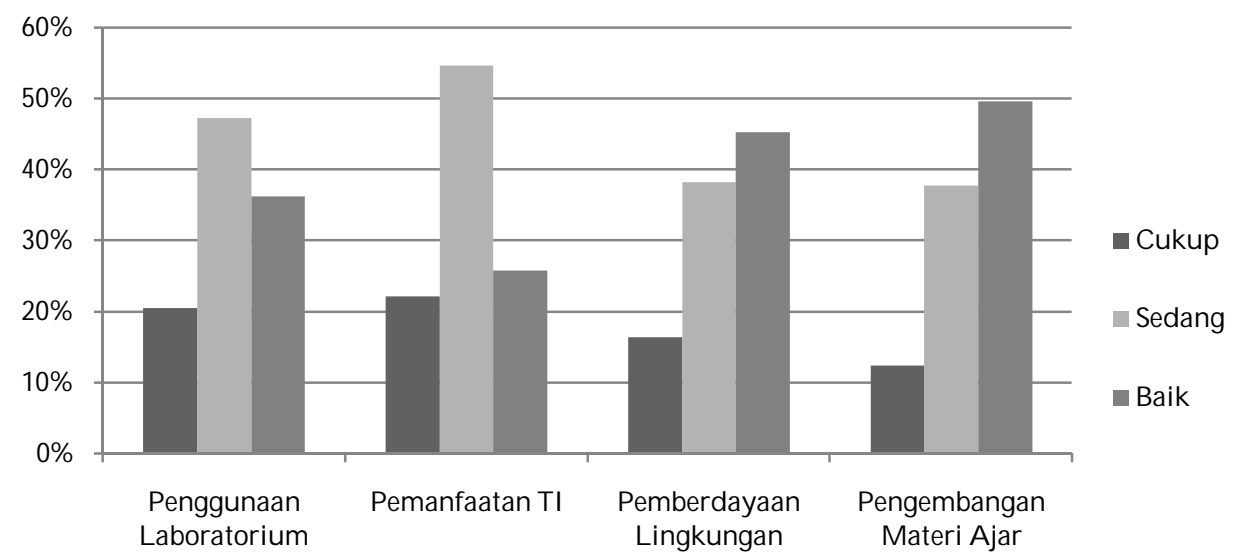

Gambar 3. Histogram Kompetensi Profesional Guru Bidang Fisika dalam Pembelajaran di SMKN Provinsi Lampung

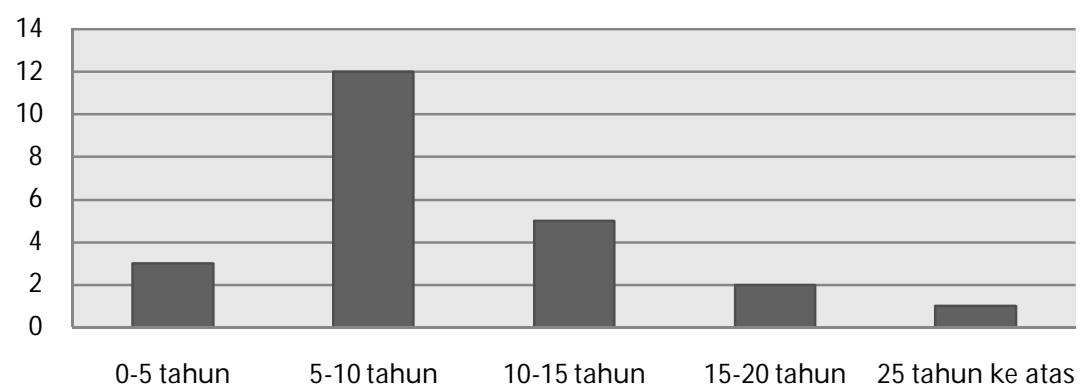

Gambar 4. Histogram Jumlah Guru menurut Lama Mengajar Bidang Studi Fisika di SMKN Provinsi Lampung 
Data yang dihasilkan dalam penelitian dapat diuraikan dan dianalisis sebagai dasar acuan dalam upaya peningkatan pemahaman dan kemampuan serta pengimplementasian KTSP oleh guru-guru Fisika di SMK se-Provinsi Lampung. Sesuai dengan RPP dapat dijelaskan bahwa hampir $75 \%$ dari tujuan pembelajaran Fisika berkaitan dengan kegiatan laboratorium/praktikum atau melalui proses pengamatan, pengukur- an, dan penggunaan alat percobaan dan praktik materi fisika. Pendekatan pembelajaran fisika yang digunakan diharapkan dapat menggiring para peserta didik mampu menemukan sendiri konsep dan prinsip pisika melalui percobaan yang dilakukan sendiri atau kelompok dan didiskusikan agar diperoleh pemahaman yang optimum yang diatur oleh guru sebagai fasilitator dalam proses belajar mengajar.

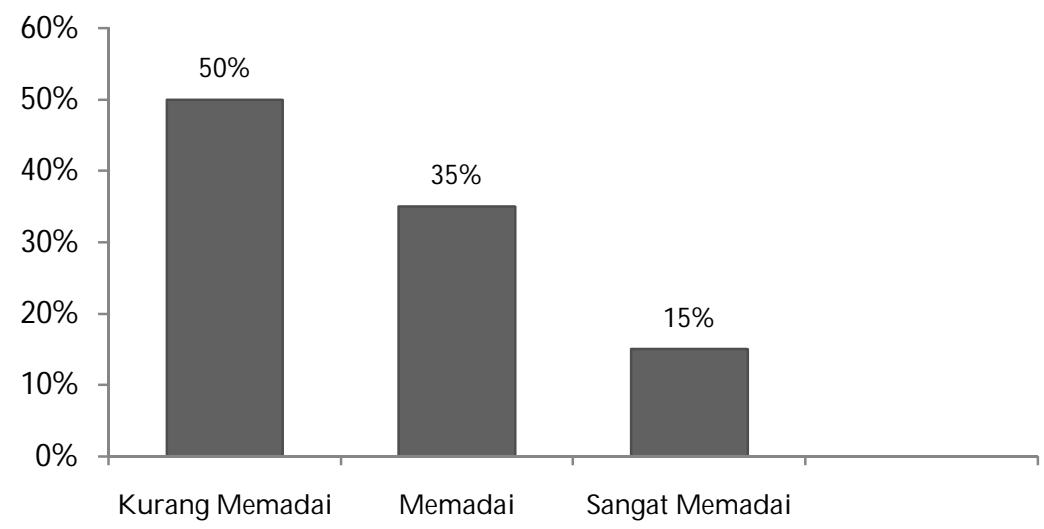

\section{Gambar 5. Histogram Sarana Pendukung Praktik di SMKN Provinsi Lampung}

Jumlah guru fisika yang ada di SMK sangat variasi, yaitu berkisar antara satu atau dua orang dengan latar belakang beragam. Pelatihan yang diikuti guru fisika juga masih sangat sedikit yang menyebabkan rata-rata guru fisika belum mampu menyampaikan mata pelajaran fisika dengan terarah. Secara manajemen pembelajaran fisika di SMK pada umumnya dilakukan dengan baik dilihat adanya rencana program pembelajaran (RPP) hampir semua guru fisika melakukan persiapan dengan baik, sampai pada evaluasi pembelajaran.
Proses pelaksanaan pembelajaran cukup beragam mengingat sarana pendukung di setiap sekolah berbeda tergantung dari sarana yang tersedia. Tenaga pengajar fisika yang terbatas, terutama dilihat dari segi kuantitas sangat kurang dibandingkan jumlah peserta didik di setiap sekolah sehingga sering dilakukan kebijakan oleh kepala sekolah untuk menugasi guru bantu yang dianggap mampu untuk memegang pelajaran fisika yang berdampak pada kemampuan peserta didik. Terbatasnya guru fisika dalam jumlah membawa dampak pada beban meng- 
ajar yang padat sekaligus menjadikan guru fisika sangat jarang melakukan penelitian pengembangan pendidikan.

Berdasarkan teori yang melandasi penelitian ini, kompetensi guru fisika yang diteliti, dikhususkan pada kompetensi pedagogik dan kompetensi profesional. Hal ini dilakukan atas dasar keterjangkauan penelitian. Pembahasan difokuskan pada kompetensi pedagogik dan kompetensi profesional dari guru yang mengampu mata pelajaran fisika di SMKN di Provinsi Lampung.

Secara substansial, konsep KTSP dalam meningkatkan pembelajaran bidang studi fisika dikembangkan berdasarkan pada prinsip-prinsip pembelajaran terpadu yang holistik dan pembelajaran berbasis lingkungan. Pendekatan holistik dalam pembelajaran didasari oleh teori Gestalt. Gestalt berasal dari bahasa Jerman yang berarti whole configuration. Pendekatan ini menekankan bahwa pengembangan pemahaman baru merupakan suatu bentuk pengembangan individu yang utuh, pola, kesatuan dan keseluruhan yang melibatkan semua aspek dalam kehidupan anak. Sukmadinata (2005:55), berkenaan dengan konsep Gestalt mengemukakan bahwa belajar merupakan proses pengembangan insight atau pemahaman baru, pemahaman terjadi apabila individu menemukan cara baru dalam menggunakan unsur-unsur yang ada dalam lingkungannya.

Dipandang dari pendekatan holistik konsep KTSP diharapkan dapat menyelenggarakan kegiatan pembelajaran yang menyeluruh, utuh dan konkret.Pengemasan pembelajaran dalam bidang fisika di SMK yang tidak terpisah-pisah dan selalu melihat suatu objek permasalahan dalam keutuhan dan keseluruhannya sehingga memungkinkan peserta didik belajar bermakna, otentik dan aktif. Pembelajaran fisika yang diselenggarakan seharusnya sesuai dengan bidang kejuruan yang terdapat di SMK tersebut. Konsep dasar fisika yang berkenaan dengan fisika tersebut dapat dipahami dengan baik oleh peserta didik.

Hal ini berdampak pada kompetensi guru fisika itu sendiri masih perlu ditingkatkan untuk mendapat hasil yang optimum dalam pembelajaran. Terkait dengan faktor eksternal yang dapat memengaruhi kinerja guru Fisika di SMK se-Provinsi Lampung diperlukan kemauan strategis oleh para pengambil kebijakan mengingat faktor demografis dan budaya yang sangat beragam sehingga dapat diharapkan memberi informasi yang signifikan, khususnya dalam mengupayakan dukungan infrastruktur.

\section{PENUTUP}

\section{Kesimpulan}

Berdasarkan hasil analisis data penelitian tentang kompetensi guru Fisika dalam penerapan KTSP oleh guru fisika di SMK Negeri di Provinsi Lampung diperoleh informasi bahwa kompetensi guru fisika dalam pembelajaran Fisika di SMKN cukup bervariasi ditinjau dari beberapa aspek yang dapat disimpulkan sebagai berikut.

- Kompetensi profesional guru Fisika di Provinsi Lampung cukup baik yang didukung oleh data tentang latar belakang pendidikan, pengalaman mengajar, keikutsertaan dalam 
kegiatan ilmiah, dan kemampuan membimbing karya ilmiah peserta didik.

- Kompetensi pedagogik guru fisika SMKN di Provinsi Lampung cukup baik yang terlihatbahwa merekamampu mengimplementasiklan KTSP baik dalam hal merencanakan, mengorganisasi, melaksanakan, mengevaluasi, maupun mengembangkan proses pembelajaran yang sesuai dengan potensi lingkungan.

- Sarana teknologi informasi (TI) dan laboratorium dalam membantu guruguru fisika baik secara individual maupun kelompok dalam meningkatkan layanan proses pembelajaran fisika yang memenuhi standar tampak belum memadai.

\section{Saran}

Untuk peningkatan kualitas kompetensi guru fisika, perlu dilakukan beberapa hal, di antaranya sebagai beriku.

- Rekrutmen guru fisika diharapkan dari jenjang dan latar belakang pendidikan yang linier.

- Peningkatan forum komunikasi ilmiah bagi guru-guru pengampu mata pelajaran fisika untuk mendukung peningkatan kualitas bagi guru fisika.

- Revitalisasi laboratorium fisika dengan dukungan sarana dan alat-alat laboratorium yang disesuaikan dengan kebutuhan jurusan yang ada di SMK.

- Perlunya tambahan infrastruktur Teknologi Informasi (TI) yang sangat mendesak bagi guru-guru fisika baik secara individual atau kelompok untuk meningkatkan layanan proses pembelajaran dan mengingat akses teknologi informasi oleh guru yang terlihat masih rendah.

\section{UCAPAN TERIMA KASIH}

Penelitian ini dapat berlangsung dengan dukungan Direktorat Pembinaan SMK dalam pelaksanaan kegiatan KKN Tematik Pendampingan SMK, kerjasama Lembaga Penelitian dan Pengabdian kepada Masyarakat Universitas Negeri Jakarta dengan Direktorat Pembinaan SMK Kemendiknas tahun Anggaran 2010. Oleh karena itu, penulis ingin menyampaikan rasa terima kasih yang setulus-tulusnya kepada semua pihak yang terkait. Terakhir, penulis mengucapkan terima kasih kepada Redaktur dan Staf Jurnal Cakrawala Pendidikan Universitas Negeri Yogyakarta yang telah memberi kesempatan untuk memublikasikan artikel hasil penelitian ini.

\section{DAFTAR PUSTAKA}

Badan Standar Nasional Pendidikan. 2006. Panduan Penyusunan Kurikulum Tingkat Satuan Pendidikan Dasar dan Menengah, Jakarta: BNSP.

Hamalik O. 2002. Pendekatan Guru Berdasarkan Kompetensi. Jakarta: Bumi Aksara.

Kunandar. 2007. Guru Profesional Implementasi Kurikulum Tingkat Satuan Pendidikan(KTSP) dan Persiapan Menghadapi Sertifikasi Guru. Jakarta: PT Raja Grafindo Persada. 
Mulyasa, E. 2008. Standar Kompetensi dan Sertifikasi Guru. Bandung: PT. Remaja Rosda Karya.

Departemen Pendidikan Nasional. 2006. Peraturan Pemerintah Republik Indonesia Nomor 19 Tahun 2005 tentang Standar Nasional Pendidikan. Jakarta: Badan Standar Nasional Pendidikan.

Reif, F. 1994. "Understanding and Teaching Important Scientific thougt Processes". American Journal of Physics, 63,(1) pp. 17-32.

Sudjana, N. 1988. Dasar-dasar Proses Belajar-Mengajar. Bandung: Sinar Baru Algensindo.
Soekamto, Toeti dan Winataputra, Udin Saripudin.1997.Teori Belajar dan Model-model Pembelajaran. Jakarta: Depdikbud.

Sukmadinata, N. 2005. Pengembangan Kurikulum: Teori dan Praktek. Bandung: Remaja Rosdakarya.

Supriyadi, D. 1998. Mengangkat Citra dan Martabat Guru. Yogyakarta: Adicita Karya Nusa.

Usman, M. U. 1995. Menjadi Guru Profesional. Bandung: Remaja Rosda Karya. 